\title{
THE RELATIONSHIP BETWEEN FORMAL AND INFORMAL INSTITUTIONS FOR GOVERNANCE OF PUBLIC TRANSPORT
}

\begin{abstract}
The purpose of this paper is to understand the relationship between the formal (governance established in law) and informal institutions (governance not established in law) that underpin the planning, operation and improvement of local and regional public transport, by using case studies of four countries: Britain (more specifically England, outside London); the Netherlands; Germany; and Sweden. The paper uses a framework drawn from the literature on institutional change to analyse the interplay between the formal governance structures and the other actors and organisations that have an influence on public transport, the formal and informal relationships between them, and how informal institutions emerge to increase the effectiveness with which public transport is delivered.
\end{abstract}

By selecting countries with some similarities in institutional structure, it is possible to explore how relationships can differ even within a relatively similar overall framework for public transport. Drawing on qualitative research with actors in the different countries, the research explores how informal institutions help actors negotiate the constraints of formal, statutory institutions. Findings reveal that informal institutions smooth the critical interfaces where formal institutions were producing sub-optimal public transport, thus providing evidence that the two modes of governance are, in fact, highly complementary.

Keywords: Governance, Formal, Informal, Institutions, Organisations, Passenger Transport, Public Transport, Collaboration 


\section{Introduction}

West European public transport has undergone quite fundamental reforms during recent decades (van de Velde 1999). These reforms have created points in the planning and organisation of the public transport system where formal structures may produce sub-optimal outcomes (Sørensen \& Longva, 2011). In some countries, this has resulted in more fragmented transport operations on the ground (O'Sullivan \& Patel, 2004; van de Velde and Wallis, 2013). For the purposes of this research, such points are termed “critical interfaces”. In this paper we explore how planning, operation and improvement of local and regional public transport are managed in situations where the formal institutions (governance established in law) are not adequate, and informal institutions (governance not established in law) have arisen to play a complementary role. This is done by comparing and contrasting case studies of four countries: Britain (more specifically England, outside London); the Netherlands; Germany; and Sweden. The paper identifies certain "critical interfaces" in the public transport sphere where sub-optimal transport was being delivered and where better collaboration is needed in order to deliver measures and policies that will help make public transport more efficient. In such situations, informal institutions become important if progress is to be made towards more effective public transport. While previous work has considered individual countries' governance structures for public transport, there is a lack of comparative studies; in addition, this paper adds to knowledge by considering how the informal works to support the formal in the operation and improvement of public transport. More specifically, the paper uses the literature on institutional change to chart the process through which

the informal governance form emerges and how it interacts with the formal governance structure already in place.

The paper first briefly reviews relevant previous literature in this area as well as the literature on institutional analysis, before presenting an analytical framework that is later used to compare the case studies. After explaining the empirical methods used, the paper then moves on to provide a taxonomy of formal and informal structures in Sweden, Germany, England outside London and the Netherlands. It then identifies a number of critical interfaces and uses case studies of individual actions to demonstrate how the informal institutions have arisen to negotiate these situations. Finally, conclusions are drawn as to the role and importance of informal institutions in negotiating the constraints resulting from formal governance structures. 


\section{Literature review}

\subsection{Fragmentation and coordination challenges in public transport governance}

Previous research has shown that public transport governance in many cases remains fragmented and is characterised by sub-optimisation and coordination challenges. Some of the issues that have been explored in the literature are coordination and integration challenges caused by frequent changes in organisation and responsibilities among public actors at different administrative levels (Marsden and May, 2006), the need for more integrated approaches between and within policy fields related to public transport (e.g. Priemus 2010; Rivasplata, 2012) and the potential importance of more specific regional objectives for public transport (Berman et al. 2005). Along a similar line, Marsden and May (2006) discuss the need for conurbation-wide authorities with financial resources and executive powers to enable the implementation of public transport policies.

There is also research that explores the impact of governance modes for public transport development. Sørensen and Gudmundsson (2010) build on Powell’s (1990) distinction between market, hierarchy and network in their analysis of urban transport partnerships. They focus specifically on the increased importance of the network mode in contemporary public transport governance, which increases the importance of trust, reciprocity and effective information exchange among actors. The idea is further developed by Sørensen \& Longva (2011) who direct focus towards specific types of coordination mechanisms in public transport governance. Other studies examine how organizational structures, policies and goals that are explicitly stated and regulated in formal frameworks, as well as norms, traditions, ways of working, etc., that are not explicitly stated (but still influence public transport planning and management substantially), together form specific "steering cultures" that influence the actions and collaboration of public transport organisations (Hansson, 2013; Hrelja, 2015).

Another strand in previous research has focused on the development of informal arrangements that aim to compensate for problems stemming from fragmented formal institutional arrangements. For instance, Pangbourne (2007) analysed the emergence of voluntary regional transport partnerships in Scotland, and discussed the interplay between statutory and voluntary transport governance arrangements. Similarly, Gray et al. (2017) stressed the importance of institutional alignment, and explored the interplay between institutional hardware and software in the implementation of lowcarbon policies in practice. In a recent study of urban carbon management in the UK and 
Germany, Marsden and Groer (2016) note that even though formal institutional structures always matter, it is important to realise the importance of the broader governance environment, and the role of politics and economic priorities in practice.

While it is clear that the planning, operation and development of local and regional public transport requires increased coordination and organisational interplay which involves both formal and informal institutions, deeper insights are needed when it comes to the process by which informal institutions emerge, and the way such informal institutions function in practice. A systematic approach to analysing this relationship can be facilitated by turning to the institutional literature.

\subsection{Formal and informal institutions}

Institutional analysis developed from two major traditions: economics (identifying institutional forms to lower transaction costs, cf. Coase, 1983; Williamson, 1975, 1985; North, 1990) and sociology, generally divided into three types: rational choice, sociological and historical or evolutionary (Scott, 2008a). Rational choice institutionalism views institutions as the outcome of market behaviour (Martin, 2000), with a focus on reducing transaction costs and solving collective action problems, meaning that rational choice institutionalism overlaps noticeably with the economic tradition. Sociological institutionalism relates to "culturally based social repertoires, routines and networks of trust, cooperation, obligation and authority” (Martin, 2000; p. 82). Scott (2008b; p. 58) writes that "compliance occurs in many circumstances because other types of behaviour are inconceivable; routines are followed because they are taken for granted as 'the way we do these things."' In historical institutionalism, institutions are defined as "the products of historically-situated interactions, conflicts and negotiations amongst different socioeconomic actors and groups.” (Martin, 2000; p. 82). In this tradition, focus is often directed towards asymmetries of power, path dependence and unintended consequences created over time (March and Olsen, 1984; Hall and Taylor, 1996;).

A vast literature exists on institutional definitions, which lies beyond the scope of this paper. For example, North (1990; p. 98) defines institutions as "the humanly devised constraints that structure political, economic and social interaction.” For Jessop (2001; p. 1230), institutions are "complex emergent phenomena, whose reproduction is incomplete, provisional, and unstable, and 
which coevolve with a range of other complex emergent phenomena.” Aoki (2007; p. 6) suggests that institutions are "self-sustaining, salient patterns of social interactions, as represented by meaningful rules that every agent knows and are incorporated as agents' shared beliefs about how the game is played and to be played.” The most widely used distinction between institutions and organizations is provided by North (1990), for whom institutions represent the rules of the game, while organisations are the players, yet others feel that organisations can themselves be institutions, particularly legal and cultural organisations. Selznick (1996; p. 275) suggests that "Because many stated "goals" are too vague and abstract to be effective in determining policy choices, ... the typical large organization is better understood as a coalition, governed by multiple rationalities and negotiated authority, than as a unified system of coordination.”

North (1991; p. 98) points out that institutions "consist of both informal constraints (sanctions, taboos, customs, traditions, and codes of conduct), and formal rules (constitutions, laws, property rights).” Moreover, as highlighted by González and Healey (2005), government influence or capacity to innovate is rooted not only in formal but informal institutions. Of particular relevance to this paper, the authors state (p. 2056) that innovation capacity "is not just defined by formal laws and organisational competences, but is embedded in the dynamics of governance practices, with their complex interplay of formal and informal relations.”

\subsection{Analytical framework}

Given the largely economic background of institutional analysis, many applications to the field of transport have, unsurprisingly, been in freight transport, such as the transference of organisational structure in sea ports (Ng and Pallis, 2010) or the transformation of institutional settings through transport corridor development (Monios and Lambert, 2013). Applications to passenger transport have focused more on the sociological tradition of analysis. For example, Pemberton (2000) applied Amin and Thrift's (1995) “institutional thickness” concept to a study of transport governance in the northeast of England. The findings were that even in a region with high institutional thickness resulting from strong, clearly-defined institutional presences with high interaction and a common agenda, more attention is needed on the interaction between governance scales and the relationship between what may be considered transport stakeholders and other relevant actors. 
More recently, Marsden and May (2006) analysed the different ways of managing and regulating the interaction between the public and private sectors. Particularly challenged by this system are attempts at integrated strategies such as public transport, thus there often remains the need for informal mechanisms. There is some evidence of an increased similarity of formal governance structures in transport due to various influences such as political devolution (Shaw et al., 2009) or processes of policy transfer (Monios, 2017). Such formal governance forms are not always successful as this convergence is sometimes driven more by normative influences such as public legitimacy than effectiveness (Marsden et al., 2014). The aim of this paper is to focus on the process of how informal institutional forms arise, thus we draw on the literature on institutional change.

Groenewegen and de Jong (2008) applied the new institutional economics models of Williamson and Aoki to an analysis of institutional change in road authorities in the Nordic countries. They identified the importance of political power play and cognitive learning among actors and highlighted that institutional change "has little to do with a gradual smooth learning process among actors in the institutional system in the direction of stable cost-minimizing equilibrium" (p. 64). Thus, while they do use the term "equilibrium" in their framework, there is no implication that this is a stable and unchallenged state, as is clear from the literature in section 2.2 (cf. also Martin, 2010). Groenewegen and de Jong (2008) therefore developed a dynamic ten-step model through which actors become "institutional entrepreneurs". These actors benchmark their own "institutional equilibrium" against a new "pool of ideas", then spread this new belief system through "windows of opportunity”, a concept with a long history going back to Kingdon (1984).

The framework becomes more dynamic once it focuses on the key elements of the change process itself. Actors use their own "power instruments or resources" to effect change while also potentially dealing with "reactive moves made by the formerly dominant actors" (pp 68-9). This focus on ideas and dissatisfied actors draws a strong link between economic and sociological approaches to institutional analysis, which derives from the key literature discussed in section 2.2 as well as reflecting other theoretical approaches to policy conflict and design rationality such as the frame reflection approach of Schön and Rein (1984). 
The literature in section 2.1 showed different types of coordination and integration challenges that arise in fragmented institutional settings. In our analysis, we want to highlight the emergence of informal arenas and processes, and what role they play for increasing the effectiveness with which public transport is delivered. As mentioned above, we focus the attention specifically towards “critical interfaces”, i.e. points in the planning and organisation of the public transport system where formal structures are insufficient for managing key issues of relevance for the outcome of the process, resulting in the need for informal structures to negotiate the interface.

The analytical framework thus needs to capture how informal institutions arise to smooth or ease these critical interfaces. For this purpose, we apply a simplified version of the framework developed by Groenewegen and de Jong (2008):

1. Old equilibrium: some actors’ preferences fulfilled more than others

2. Some actors identify the need for change

3. These actors become institutional entrepreneurs by searching for new ideas

4. A pool of ideas is found against which to benchmark the current system

5. Institutional entrepreneurs use their influence to spread the new ideas

6. Windows of opportunity: change in political or bureaucratic officials or organisational transformation provides the moment for the institutional entrepreneurs to get their ideas officially adopted

7. Potential for reactive moves made by the formerly dominant actors

8. New equilibrium is reached.

This framework aids a focus on the dynamics of institutional change, understanding that any state of perceived equilibrium is not a fixed position but merely considered an equilibrium in terms of the evolution of the current initiative being studied (i.e. the timescale of the specific actions undertaken in the case studies). This framework was chosen because, while informal collaboration may be considered an ongoing process, our interest is on how the informal governance form emerges and develops. The application of the framework to the case studies will enable a clear identification and a deeper exploration of the specific actions driving this process. 


\section{Methodology}

The research is based on a qualitative case study methodology, which is appropriate to the "how" question being asked in this paper; namely, how do informal institutions smooth the critical interfaces where formal institutions were producing sub-optimal public transport. Case studies are also an appropriate methodology when the phenomenon being studied cannot be separated from its context (Yin, 2009).

The analysis is based on cross-case comparison of informal public transport governance in four European countries: Britain (more specifically England, outside London); the Netherlands; Germany; and Sweden. The case study countries were selected in order to understand how structures can be different even within a relatively similar overall context for public transport. In each case, public transport governance is structured within three primary levels of government but with primary control of public transport at the regional level, with a regulated system of public and private companies running public transport services under contract to the public authority. Differences outside of these similar official frameworks are postulated to relate strongly to informal processes of governance, thus being suitable for the theoretical aims of this research. A taxonomy of formal structures in Sweden, Germany, England outside London and the Netherlands is made to identify a number of critical interfaces. We then use case studies of individual actions to demonstrate how the informal institutions are used to negotiate these critical interfaces; much of the information in the paper on the functioning of these institutions is drawn from both the interviewees and document analysis.

The cases were identified through interviews with key actors in public transport related organisations, selected as having exerted a strong impact on the successful delivery of high quality public transport. The case studies illustrate how informal structures can help to negotiate the tension between local and regional objectives (for example, in public transport service delivery or in land use planning decisions), the financing of local and regional public transport, improving the quality of service provided and the process of managing complex infrastructure investments.

This resulted in the selection of the following four case studies:

- Managing the relationship between public transport and land use planning in West Gothia in Sweden (where Gothenburg is the major urban centre). 
- Bus service planning in the Aachen region of North Rhine Westphalia in Germany.

- Voluntary bus quality partnerships in the West Midlands of England (around Birmingham).

- The Randstadrail metro/LRT scheme in the Rotterdam/The Hague area of the Netherlands.

The case studies are different in nature and scale but they are nonetheless comparable because they all represent areas of activity where the formal structures in existence do not deliver sufficiently. It could be argued that the case studies are unrepresentative because they are examples of how critical interfaces have been managed successfully and that unsuccessful examples should also be considered; otherwise the paper could be accused of "cherry picking” case studies. However, since the main aim of the paper is to understand how informal institutions can be used to mediate critical interfaces, and not to make a judgement on what constitutes successful use, it is not invalid to consider only successful examples. In addition, the case studies from Britain and Germany are not isolated or unique - Tariff Unions (Verkehrsverbuende) across Germany standardly manage bus service planning, while voluntary quality partnerships are an informal institution found in many towns and cities across Britain outside London. Furthermore, it is problematic to find unsuccessful examples of attempts to build informal institutions since this informality means that these examples, if not successful, fall by the wayside and their existence is often not recorded; and actors are often unwilling to discuss initiatives that have not enjoyed some measure of success. Nonetheless, the model of the informal institution (as opposed to the unsuccessful individual example) - be it a voluntary partnership, or a Tariff Union - persists more widely because the critical interfaces that they are intended to mediate also persist.

Data for the cases were drawn from document reviews and semi-structured interviews with key actors in different public transport related organisations. Documentation for the cases was sourced from publicly available publications in the local languages, which explained the structure of the formal and informal institutions examined and the current system of public transport and land use planning. Interview questions were developed based on the analytical framework developed from the literature. Organisations interviewed included municipalities, regional public transport organisations, the county council (or equivalent), politicians, operators and those involved in local economic development organisations. Interviewees were asked about the organisations with an interest in public transport and the nature of that interest; the formal relationships between these 
institutions; the critical interfaces that these relationships have to negotiate; and the existence and effectiveness of informal institutions to aid this process. Wherever possible, interviewees were asked to exemplify their responses with references to specific actions that the organisations have to deliver, such as new infrastructure projects, or agreements on fare increases.

Due to the identification of relevant interviewees, four interviews were carried out in the Swedish case study (the regional public transport authority, the city of Gothenburg, a Regional Association of Local Authorities and the Swedish National Transport Agency), three in the British case study (a major bus operator, the regional public transport authority and a municipality) and one each in the Netherlands (a regional public transport organisation) and Germany (a city authority). Interviewees were selected via personal contacts or personal recommendation. Informed consent was dealt with by verbal agreement with the interviewees, confirming that anonymity would be maintained, and by giving them the opportunity to read and comment on a summary of the interview findings. Interviews were transcribed and a manual content analysis performed in order to draw out and categorise key themes but these themes were not limited to those in the theoretical framework posited in Section 2 of the paper. Instead, the content analysis looked for frequentlyoccurring themes that are reported in Section 5 of the paper and then discussed in Section 6. Data was triangulated from the interviews and documents and, especially in cases with fewer interviewees, care was taken to base conclusions on factual information regarding events that took place rather than individual opinion. The authors recognise that the number of interviews is small but we argue that all conclusions have been drawn from verifiable facts of the case rather than opinions of the interviewees. The analysis in the paper deals with documented institutional changes rather than asking people about their perceptions, and therefore more interviewees would not necessarily strengthen the analysis.

\section{Formal institutions}

Due to space limitations, this section provides a necessarily brief overview of formal institutional structures in each of the four case countries. The formal (this section) and informal (section 5) structures identified are summarised in Table 1. 


\subsection{Sweden}

In Sweden, municipalities and county councils have a common financial and political responsibility for public transport. Municipalities and county councils in each county have since the 1970s formed Public Transport Authorities (PTAs) and delegated the planning and operation of public transportation to county transport companies (Länstrafikbolag), such that counties and municipalities share the cost of public transport. In 2012, a new Public Transport Act formed new regional PTAs, responsible for developing the public transport system in each county. The PTA is responsible for all local and regional public transport services (regional rail, local and regional bus and in Stockholm and Gothenburg LRT) under a Public service obligation and securing them via competitive tender. The new PTAs have a much clearer strategic role compared with the previous authorities. Strategic decisions, which previously were often taken by county transport companies, are now made by the PTAs to increase political control of public transport. The county public transport companies continue to exist but with a clearer function. The new Act also meant that commercial companies are free to set up public transport services anywhere in the country (Van de Velde and Wallis, 2013).

It is also important to note that there are other actors who play a role in regional and local public transport. The national transport agency, Trafikverket, is the owner and operator of national roads and all rail infrastructure. It is increasingly working with public transport organisations and municipalities to improve sustainable transport options in localities and regions. It is also, via the 5 yearly National Transport Infrastructure Plan, a co-funder of major new transport projects such as busways, trams, railways and new roads. (Funding for operating subsidies and smaller new schemes comes from local income tax. However, for major schemes, municipalities and regions are forced to seek match funding from the national level.) As well as Trafikverket, there is the Länsstyrelsen, which is the representative of the state at the County level; and organisations such as Samtrafiken, a body set up to provide integrated public transport ticketing and information nationwide. Local land use planning is still, legally, the exclusive competence of local authorities, with any regional planning function being advisory. This can potentially lead to a disconnection between regional public transport and local land use planning. 


\subsection{Germany}

Germany has a federal government (Bundesregierung), but is then divided into 16 federal states (Bundesländer). At the more local level, there are counties (Kreise), below these municipalities (Gemeinde) but also county-free cities in the larger urban areas. Thus in some areas there are two levels of local government, and in others, only one. In the whole of Germany there are around 12,000 municipalities that sit within 323 counties, plus 116 county-free cities. In land use planning municipalities and county-free cities must ensure that their plans and planning decisions are in line with higher level plans and laws, but in practice they have a great deal of autonomy in deciding how much they should take these into account (Welsch, Haustein and Kemming, 2008).

The precise organisation of regional rail and local and regional bus and tram services varies somewhat across federal states, so here the example of North Rhine Westphalia (NRW) is given. In this federal state, counties and county free cities are responsible for procuring regional rail services, and longer distance interurban bus services. In practice they group together into special purpose agencies (Zweckverbände) to procure such services for larger areas, for example the region around Aachen. In some cases these Zweckverbände also own and operate local/regional rail infrastructure (such as for example Regionbahn near Stuttgart). Within individual municipalities, public transport services are run by the municipally-owned operator or procured from private bus operators. Some smaller municipalities delegate this task to the county.

The coordination of all public transport timetables and integrated ticketing of buses, trams and regional trains is carried out by a tariff union (Verkehrsverbund) made up of local government representatives and public transport operators and governed by the Zweckverband. For these areas, NRW law also requires them, the counties, county free cities and municipalities to collaborate to produce around once every five years a local public transport development plan (Nahverkehrsplan).

The Federal Government has a majority stake in the incumbent national rail operator, DB; owns the vast majority of the railway infrastructure plus national roads; and is a very important financier of investments in new transport infrastructure. As such, it has since the 1960s provided match funding for regional and local transport. In 1996 the planning and provision of regional rail services was devolved to the Länder which at the same time received much more funding for 
them, leading to a significant growth in local and regional rail services. In some Länder these are planned and procured directly by the Land itself, and in others, by lower levels of government.

\subsection{England outside London}

In England outside London since the mid-2000s, public transport planning has been the responsibility primarily of national government (for rail) and the private sector for bus services. There is no regular national transport plan to structure transport investment. Municipalities, in most areas just on a single tier, provide infrastructure on the road for buses, and lobby for and may part-fund rail improvements. Control of franchised rail services is the responsibility of national government, while buses are run in a deregulated competitive market where operators decide routes, fares and frequencies and the public sector can only intervene to fill any gaps in the commercial network that it sees as socially necessary. In metropolitan areas such as Greater Manchester a regional body (now called combined authorities, CAs), governed by politicians from constituent local municipalities, coordinates local and regional public transport and in some areas operates certain services such as metros, LRT and ferries. Land use planning is the sole responsibility of local (municipal) government, although the private sector drives most actual development and has increasing flexibility in so doing.

Since 2010 statutory bodies called Local Enterprise Partnerships (LEPs) have controlled allocation of the bulk of local public transport infrastructure funding that comes from central government, rather than this money going to municipalities or CAs. The LEP's decision making body is a board made up of largely private sector representatives appointed directly by national government. Local politicians therefore have a much lesser influence in the allocation of these funds than they

previously did. Unlike in Sweden or Germany, municipalities raise very little of their income from local taxes and are thus reliant on national government for transport funding.

\subsection{Netherlands}

The key formal responsibility for the planning and delivery of local and regional public transport in the Netherlands lies with the Provinces, the middle tier of government between municipalities and the national level. Until recently, provincial powers were delegated to regional public transport bodies (accountable to boards of selected local politicians with voting powers on the basis of the population of their respective municipality) across the entire country, but these 
regional authorities were abolished in 2015, with the exception of Amsterdam and Rotterdam/The Hague, and elsewhere powers have reverted to the Provinces as part of a general central government move to reduce the number of levels of government in the country as a whole.

Funding for the subsidy of public transport comes from national government to the Provinces and then on to the regional authorities, where these exist. Rail services are provided largely by the publicly-owned national rail operator NS (only on secondary routes in the north and east of the country are rail services competitively tendered) while buses, trams and metros are operated on a directly awarded or competitive contract by a mixture of city-owned and private operators. Rail infrastructure is owned by a nationally-owned and funded body, ProRail. Land use planning remains the responsibility of municipalities; the Provinces have the legal power to intervene in the making of local land use plans and individual planning decisions, but rarely do, for political reasons. 
Table 1: Institutional structures and funding for public transport, comparison countries

\begin{tabular}{|c|c|c|c|c|}
\hline & England (outside London) & Germany & Netherlands & Sweden \\
\hline $\begin{array}{l}\text { Basic formal } \\
\text { institutional } \\
\text { structure }\end{array}$ & $\begin{array}{l}\text { - } \text { EU - laws on TENs, } \\
\text { procurement of Public Transport } \\
\text { (PT) } \\
\text { - National government } \\
\text { - Municipalities } \\
\text { - Local Enterprise Partnerships } \\
\text { (LEPs) } \\
\text { - In certain regions, "Combined } \\
\text { Authorities" with increasing } \\
\text { public transport coordination and } \\
\text { management role } \\
\text { - National and municipal } \\
\text { government directly elected } \\
\text { - LEP is appointed by national } \\
\text { government in untransparent } \\
\text { process and decides where to } \\
\text { allocate most PT infrastructure } \\
\text { funding }\end{array}$ & $\begin{array}{l}\text { - EU - laws on Trans-EU networks } \\
\text { (TENs) affect regional rail infra, } \\
\text { procurement of public transport } \\
\text { - Federal govt - national transport } \\
\text { plan, infra funding, national rail } \\
\text { infra, legislation } \\
\text { - Länder - legislation, produce } \\
\text { strategic land use plans } \\
\text { - "County free” } \\
\text { cities/Counties } \\
\text { - Municipalities } \\
\text { - All of the above except EU } \\
\text { directly elected }\end{array}$ & $\begin{array}{l}\text { - } \text { EU - laws on TENs, procurement of } \\
\text { PT } \\
\text { - } \text { National government } \\
\text { - } \text { Provincial government } \\
\text { Metropolitan Region (Amsterdam, } \\
\text { - Municipalities } \\
\text { - All above except EU and region } \\
\text { directly elected } \\
\text { - Region's governing board made up of } \\
\text { politicians from constituent } \\
\text { municipalities, voting on population } \\
\text { basis }\end{array}$ & $\begin{array}{lll}\text { - } & \text { EU - laws on } & \text { TENs, } \\
& \text { procurement of PT } \\
\text { - } & \text { National government } \\
\text { - } & \text { County Council } \\
\text { - } & \text { Regional public transport } \\
& \text { authority (part of County } \\
& \text { Council) } \\
\text { - } & \text { Municipalities } \\
\text { - } & \text { All above except EU directly } \\
& \text { elected }\end{array}$ \\
\hline $\begin{array}{l}\text { Control of local } \\
\text { rail planning, } \\
\text { subsidy, } \\
\text { operations }\end{array}$ & $\begin{array}{l}\text { - Entirely responsibility of } \\
\text { national government. } \\
\text { Municipalities and Combined } \\
\text { Authorities can only lobby and } \\
\text { part fund schemes (though CAs } \\
\text { may soon have greater power) }\end{array}$ & $\begin{array}{l}\text { - Länder fund regional rail subsidy } \\
\text { and infra, tram and larger bus infra } \\
\text { via larger “Zweckverband” (VVB) } \\
\text { special purpose body } \\
\text { - Historically DB national operator } \\
\text { runs regional services, this now } \\
\text { changing }\end{array}$ & $\begin{array}{l}\text { - Provincial responsibility, where there } \\
\text { are regional rail services (mostly } \\
\text { around smaller cities) } \\
\text { - In large metro regions, all rail } \\
\text { services still operated by NS } \\
\text { (national operator). } \\
\text { - Elsewhere, increasing number of rail } \\
\text { operators }\end{array}$ & $\begin{array}{ll}- & \text { County Council (PTA) } \\
\text { responsibility } \\
\text { - } \\
\text { All national rail services are open } \\
\text { access }\end{array}$ \\
\hline $\begin{array}{l}\text { Control of bus } \\
\text { planning, subsidy, } \\
\text { operations }\end{array}$ & $\begin{array}{l}\text { - Majority of services planned and } \\
\text { provided by deregulated private } \\
\text { sector companies, although these } \\
\text { receive } 45-50 \% \text { of their income } \\
\text { via public subsidies on fuel and } \\
\text { for carrying people aged } 60+ \\
\text { - Infrastructure provided by } \\
\text { municipalities and Combined } \\
\text { Authorities }\end{array}$ & $\begin{array}{l}\text { - Cities/counties -bus infra, subsidy } \\
\text { - In practice delegate bus planning, } \\
\text { ticketing, marketing to regional } \\
\text { Zweckverband (VVB) } \\
\text { - Buses and trams operated by city } \\
\text { owned and private operators }\end{array}$ & $\begin{array}{l}\text { - Provincial or metropolitan region } \\
\text { responsibility } \\
\text { - Buses and trams operated by city } \\
\text { owned and private operators under } \\
\text { direct award or competitive contract }\end{array}$ & 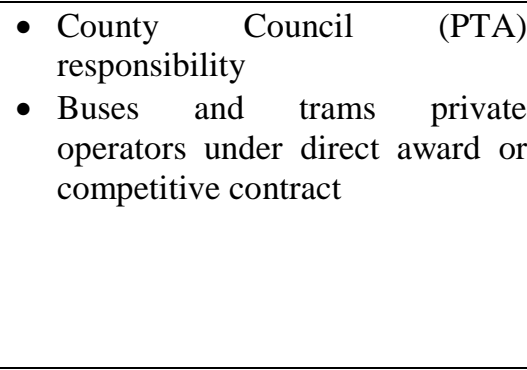 \\
\hline
\end{tabular}




\begin{tabular}{|c|c|c|c|c|}
\hline $\begin{array}{l}\text { Major new scheme } \\
\text { principal } \\
\text { financing sources }\end{array}$ & $\begin{array}{l}\text { - National government } \\
\text { - Property developers } \\
\text { - Municipal and Combined } \\
\text { Authority borrowing } \\
\text { - Most major schemes e.g. a tram } \\
\text { financed through public-private } \\
\text { partnership (PPP): private sector } \\
\text { borrows, public sector pays annual } \\
\text { “availability payment” } \\
\text { - LEP decides which schemes are } \\
\text { funded }\end{array}$ & $\begin{array}{l}\text { - Federal and Land governments } \\
\text { (funding sometime cascaded down } \\
\text { to Zweckverbände) }\end{array}$ & $\begin{array}{l}\text { - Shared national/ provincial/ } \\
\text { municipal for major schemes e.g. } \\
\text { Randstad Rail metro scheme from } \\
\text { Den Haag to Rotterdam }\end{array}$ & $\begin{array}{l}\text { - Shared national/ provincial/ } \\
\text { municipal for major schemes } \\
\text { - Lead most likely to come from } \\
\text { region but occasionally from } \\
\text { national level especially for } \\
\text { schemes in Stockholm. Generally } \\
\text { municipalities/counties raise 50\% } \\
\text { of scheme costs locally }\end{array}$ \\
\hline $\begin{array}{l}\text { Key actors (other } \\
\text { than levels of } \\
\text { government) }\end{array}$ & $\begin{array}{l}\text { - LEPs } \\
\text { - } \text { Business lobby groups e.g. in city } \\
\text { centres } \\
\text { - } \text { Bus operators (private) } \\
\text { - Rail operators (private) } \\
\text { - Rail infrastructure owner, and } \\
\text { - } \text { regulator } \\
\text { - } \text { Pational roads authority } \\
\text { - PPP consortia for largest schemes }\end{array}$ & $\begin{array}{l}\text { - DB Netz rail infrastructure owner } \\
\text { (public) } \\
\text { - Zweckverbände - public transport } \\
\text { coordinating organisations } \\
\text { - Large (city-owned) PT operators } \\
\text { - Chambers of Commerce } \\
\text { - Occasionally, public opinion } \\
\text { - Large employers, universities } \\
\text { - DB (public) }\end{array}$ & $\begin{array}{l}\text { - } \text { NS (public) } \\
\text { - Prorail (rail infrastructure owner, } \\
\text { public) } \\
\text { - Large city-owned PT operators } \\
\text { - Ministry of Infrastructure and } \\
\text { Environment }\end{array}$ & $\begin{array}{l}\text { - Trafikverket, national transport } \\
\text { agency, national rail infrastructure } \\
\text { owner. } \\
\text { - SJ, incumbent national rail } \\
\text { operator }\end{array}$ \\
\hline $\begin{array}{l}\text { Relevant policy } \\
\text { and planning } \\
\text { documents }\end{array}$ & $\begin{array}{l}\text { - Local Transport Plan (LTP: } \\
\text { municipal transport plan, 20 year } \\
\text { time horizon with 3-5 year) } \\
\text { implementation plans } \\
\text { - LEP }\end{array}$ & $\begin{array}{l}\text { - Public transport development plan } \\
\text { (Nahverkehrsplan) for region } \\
\text { - City's Transport Development Plan } \\
\text { - Zweckverband most important - } \\
\text { here decisions about schemes and } \\
\text { subsidy for public transport routes } \\
\text { are negotiated }\end{array}$ & $\begin{array}{l}\text { - National infrastructure plan } \\
\text { (entitled MIRT) every } 5 \text { years } \\
\text { - Regional public transport } \\
\text { development plan (every five } \\
\text { years) } \\
\text { - Municipalities' transport plans }\end{array}$ & $\begin{array}{l}\text { - } \text { National infrastructure plan every } \\
5 \text { years } \\
\text { - Regional public transport } \\
\text { provision plan } \\
\text { - Municipalities' own transport } \\
\text { plans }\end{array}$ \\
\hline $\begin{array}{l}\text { Key informal } \\
\text { institutions }\end{array}$ & $\begin{array}{l}\text { - Consultation aspects of LTP } \\
\text { - Voluntary bus quality partnerships } \\
\text { between municipality and bus } \\
\text { operator } \\
\text { - Voluntary regional collaborations } \\
\text { between authorities }\end{array}$ & $\begin{array}{l}\text { - Relationships within the } \\
\text { Zweckverband, particularly with the } \\
\text { Chief Executive } \\
\text { - Lower level non-binding discussion } \\
\text { forums that feed into decision } \\
\text { making of Zweckverband } \\
\text { - Consultation/participation aspects of } \\
\text { statutory plans }\end{array}$ & $\begin{array}{l}\text { - "Polder model" of negotiation and } \\
\text { consensus building: consistent } \\
\text { theme } \\
\text { - Multi-agency/actor programmes } \\
\text { such as "Beter Benutten" to tackle } \\
\text { congestion from a broad base, or } \\
\text { Stedenbaanplus in Den Haag } \\
\text { region. } \\
\text { - Round table meetings between } \\
\text { provinces /regions and NS to } \\
\text { discuss impacts of NS service } \\
\text { decisions on regional transport }\end{array}$ & $\begin{array}{l}\text { - Constituted organisations e.g. the } \\
\text { Gothenburg Region Association } \\
\text { of Local Authorities (GR) that } \\
\text { depend on consultative methods } \\
\text { in regional land use planning } \\
\text { - Consensus building processes in } \\
\text { large infrastructure schemes, eg. } \\
\text { The K2020 agreement }\end{array}$ \\
\hline
\end{tabular}


The description of formal structures and funding for public transport shows that there have been changes to formal governance structures the last two decades that change the nature of power relationships between organisations. These reforms have also led to a number of common 'critical interfaces' in the different countries where formal structures may produce sub-optimal outcomes; these include the tension between local control and funding of public transport and a more strategic regional approach to its planning, land-use planning that is more supportive of public transport, funding and delivering major improvement schemes, and what to do when responsibility for the provision of different aspects of public transport (e.g. operations, infrastructure, information) is formally divided between different organisations.

\section{Case studies of how informal institutions help to negotiate critical interfaces}

In this section we describe informal institutions that are trying to negotiate critical interfaces arising within formal structures in public transport planning and delivery in each case study country.

\subsection{Sweden: planning and transport integration}

Swedish municipalities enjoy an elevated status in the Swedish planning system, and each municipality has the exclusive right to formulate and adopt land use plans, which makes a coordinated regional approach problematic. In a few regions, as in West Gothia, the Göteborg Region Association of Local Authorities (GR), a co-operative organisation uniting thirteen municipalities, has been appointed by the government as "regionplaneorgan" under the Planning and Building which means that GR does non-statutory regional spatial planning. The County Council are PTA in the region. The county council are responsible for public transport but also for regional development and regional infrastructure planning. The formal institutional structure makes regional land use planning and public transport planning difficult.

The K2020 project is one Swedish attempt to handle planning and transport integration in West Gothia. A prelude to K2020 was the development of three regional plans (not legally binding for the municipalities) in West Gothia. The preparation of a fourth started in 2001. Instead of making a regional plan, which, like the earlier ones, risked becoming a "shelf warmer", a number of consensus building meetings were conducted among GR's member municipalities in order to increase regional consensus. GR described the process as a structured but unbiased dialogue and collaboration where the member municipalities started 
to identify key areas for regional cooperation. The process resulted in a strategy for regional physical development where GR's member municipalities agreed on how the region's physical structure should be developed. It is this regional development strategy which was the basis for K2020.

The project is the result of several attempts over the years to achieve an integrated regional, albeit non-binding, land use and public transport planning system. The K2020 project is a joint action between the West Gothia Region (County Council), the Göteborg Region Association of Local Authorities (GR), the City of Göteborg, the National Transport Agency, which aims for a $40 \%$ increase in public transport usage. The project has been in progress for several years and a proposed public transport development programme was presented in 2008, providing guidelines for the development of public transport and land use planning region, including infrastructure investments.

Prior to the signing of the K2020 agreement, a process of consensus building was carried out where the six cooperating parties, along with GR's other 12 member municipalities, all accepted that the programme would represent a common vision and the basis for planning and decision-making in respective organizations. The municipalities in West Gothia have developed local K2020 plans describing how their physical planning shall be adapted to K2020.

Interviewees described the process that has led to the K2020 as a collaborative process towards shared goals where stakeholders explore mutual benefits. One interviewee descried collaboration in the project as "co-action", in contrast to mere "collaboration" or "negotiation”. Through co-action, organisations with different goals try to create a common agenda that each organisation can itself choose how to realise: "It is better to have your own [organisation's] agenda but aim for a common goal. We meet in Rome for vacation, but how we get there everyone can choose best from their own capacity” (interview with officer, GR).

The K2020 project thus appears to achieve its aim whereby the informal structures produce shared goals and understandings of the role of public transport in local and regional land use and transport planning. This mitigates the potential dysfunction of the formal structure of regional land use planning and public transport planning. 


\subsection{Germany: bus service planning in Aachen}

While the main organisation responsible for bus service planning in the Aachen region, the Aachener Verkehrsverbund (AVV), is a formally constituted organisation, it does not have the legal power to plan and tender bus services. These are ceded to it by the City of Aachen and surrounding counties, which do possess this power. This lack of legal power means, however, that the AVV must use informal institutions to achieve consensus about changes before taking them for final political decision at its board. In spite of its lack of formal power, "in practice politicians recognise it as the responsible organisation and tend to follow its suggestions on planning public transport services in the AVV area."

An example of a critical interface for AVV is the issue of fare increases. One operator can decide that it would like to raise fares and then take the proposal to the non-binding operators' board at the AVV. AVV then has to discuss this idea with each of the three counties and City of Aachen in another forum called a regional board. The regional board has to be unanimous in supporting the idea of a fares rise. Then the issue goes back to the operators in the AVV to check that they are once again agreeable. A good example of this process was the introduction in the City of Aachen of a short distance ticket related to the boarding point rather than the zone boundary. In this case, the other counties did not want this, so this was resolved by Aachen paying more subsidy for what it wanted - unusually, the subsidy burden was not shared across all members of the AVV, but the informal institutions were used to reach this decision in a mutually agreeable way.

The collaboration processes in public transport in the Aachen region are based on many fora for initial discussions and negotiations that involve everyone with a stake - the different political parties, the operators, the urban counties, the rural counties and so on. This requires skilful negotiators and a lot of time before the formal political decision is taken, but it achieves higher input from stakeholders. For example, the head of AVV has to hold several meetings with politicians of different parties, with the operators and with the local Mobility Board before any major decision can be made; and these meetings have to be held in each county in the AVV area. While they are not obligatory and non-binding, they are a key informal mechanism to prepare for the decision in the formal AVV board. 


\subsection{England: quality bus partnerships}

A critical interface for bus service planning and improvements in England is that the deregulated regime means that the public sector cannot simply franchise additional services as its continental European equivalent would do. It is possible for municipalities in England to legally require bus operators to deliver quality improvements as a condition for the use of improved infrastructure (stops and bus lanes) but in practice very few have done so (see Rye and Wretstrand, 2014). Most have instead brokered voluntary agreements, not seeing the additional benefits of a statutory partnership as sufficient to outweigh the legal complexities.

Voluntary partnerships have delivered bus priority, improved bus stops and stations, new and cleaner vehicles at higher frequencies, real time information, improved driver training and customer service, and even house to house marketing about the improved bus service (see for example Transport for the West Midlands, 2014). These partnerships have on occasion delivered impressive rates of growth - in Brighton, England, for example, the local operator claims 5\% a year growth in passenger numbers over the past decade (Go Ahead Group Brighton Buses, 2015), although it is hard to isolate how much of this is due to the quality partnership and how much due to fares and network improvements. They have also brought about significant changes in the way that operators and public authorities work together to deliver improved public transport: as one of our interviewees in the West Midlands of England said, "What was suboptimal in the old arrangement where we didn't have partnerships, by definition we didn't have that collaboration. So, National Express West Midlands [the main bus operator] would purely make decisions down to commercial imperatives which suited their balance sheet and failed to take on board any of our objectives... [now] there is just a lot more openness between operator, TFWM and the council.”

However, other work has shown that certain conditions must be in place for these partnerships to work: as well as skilled individuals in positions of influence in both local authority and bus operator, the local bus market must be one that has the potential for growth, otherwise the bus operator will be unable to invest - the parent company will move investment resources to another city with greater potential. In addition, local politics must be supportive of investment in bus infrastructure. It is also notable that the success of partnerships can be highly variable from city to city even though both may have the same parent operating company (Rye and Wretstrand, 2014). It may be inferred from this that the success of informal institutions such 
as BQPs may be in part dependent on "soft" factors related to the organisation of the informal institution and the people involved in it (see Hrelja et al., 2017).

\subsection{Netherlands: Randstadrail}

A critical interface in all systems is the planning and delivery of major new schemes. We use the example of Randstadrail in the Netherlands to show how informal institutions in this country can help to negotiate this interface. Randstadrail is a $€ 1.5$ billion light rail scheme that links Rotterdam, The Hague and Zoetermeer (a new town to the east of The Hague) in the western Netherlands. It converted an existing north-south railway line to become a part of the Rotterdam Metro, and an existing east-west railway to become a part of The Hague tram network. Over part of the line east of The Hague, tram (light rail) and metro trains run on the same track. There is also a linked BRT scheme. Our focus is, as noted above, not on how political will and funding was secured from the various levels of government involved (national, provincial and local, who ultimately funded 50\%, 30\% and $20 \%$ respectively of the scheme), but how informal structures helped to mediate planning and delivery challenges.

Since the project involves the interoperation of metro and tram vehicles on infrastructure that was previously owned and operated by three different organisations, across administrative boundaries, and with a desire to integrate the new public transport service with land use planning, there were many ways in which the formal structures were severely challenged to deliver the project.

The organisations involved in the planning and delivery of Randstadrail were the regional public transport organisations in the Hague and Rotterdam (VervoerRegios VVRs) and the Cities of The Hague and Rotterdam as its joint promoters; the national rail operator NS; the national rail infrastructure body ProRail; the city-owned public transport operators in Rotterdam and the Hague, RET and HDM; the other municipalities along the route; the directly elected Province; and the national government as funder and “owner” of ProRail.

Provincial government lobbied for the scheme but was not itself a key funder. Prorail, the rail infrastructure operator, were crucial (and part of the ministry, but according to an interviewee acting as an almost autonomous stakeholder sometimes). The support of HDM and RET was also essential to the success of the scheme; although they are owned by the cities, they are 
also rather autonomous. NS were very supportive because they wanted to stop operating the heavy rail lines concerned.

The scheme took in total 20 years between conception and opening - 12 in planning and 8 in delivery. There were two project delivery offices, one in The Hague, one in Rotterdam, which led to what was estimated by one interviewee to be a three year delay. However, this was necessary as a way of managing the different stakeholders in the different cities. The municipalities affected by the scheme were key stakeholders for the design and upgrading of stations and for linking them to urban development and local roads, cycleways and park and ride. Keeping them in the project was critical yet challenging, and needed a significant time input from the regional authority, but this paid dividends as they have carried out (and continue to carry out) their urban development in a way that is supportive of Randstadrail.

The scheme took a great deal of time but it is probable that it would have taken even more time, or even not happened at all, without an informal approach to collaborative working based on the Dutch Polder model which, as other authors (such as Woldendorp and Keman, 2007) have shown, is an institutionalised informal institution in Dutch governance. Technicians and politicians are used to working in this way and this is how collaboration is informally governed. As our interviewee said, "Well, the arena within our own region is effective, since it's a 'çlosed' arena. All players know each other. The (in)formal rules of decision making are known.” The Stadsregio took the initiative to take forward Randstadrail, municipalities and other stakeholders became involved, there were many meetings, and ultimately agreement was reached. According to one interviewee, however, this approach can fail in schemes where there is one very large and powerful stakeholder such as NS which will tend to play other smaller stakeholders off against one another and dominate the whole process. This did not happen in the case of Randstadrail, though, since NS wanted to rid itself of a loss making suburban rail service.

\section{Cross-case analysis and discussion}

This section compares and analyses the cases, first by collating key data in table 2 . 
Table 2. Application of institutional framework to the four cases

\begin{tabular}{|c|c|c|c|c|c|}
\hline No. & Factor & Sweden - K2020 & $\begin{array}{l}\text { Germany - new bus fare in } \\
\text { context of Verkehrsverbund }\end{array}$ & $\begin{array}{l}\text { England - Voluntary Quality } \\
\text { Partnership }\end{array}$ & Netherlands - Randstadrail \\
\hline 1 & Old equilibrium & $\begin{array}{l}\text { Poor integration of land use } \\
\text { planning with public transport } \\
\text { planning. }\end{array}$ & $\begin{array}{l}\text { Fare structure for bus in Aachen } \\
\text { was problematic for City of } \\
\text { Aachen. }\end{array}$ & $\begin{array}{l}\text { Bus operators have complete } \\
\text { control over local bus services, } \\
\text { with almost no municipal } \\
\text { influence. }\end{array}$ & $\begin{array}{l}\text { Poorly integrated infrastructure } \\
\text { and services in large suburban } \\
\text { region. }\end{array}$ \\
\hline 2 & $\begin{array}{l}\text { Dissatisfaction, need for } \\
\text { change }\end{array}$ & $\begin{array}{l}\text { Resulted in K2020 initiative to } \\
\text { increase public transport use } \\
\text { partly through better integration. }\end{array}$ & See above. & $\begin{array}{l}\text { Municipalities have public } \\
\text { transport policy objectives that } \\
\text { they seek to achieve; operators } \\
\text { may wish for additional } \\
\text { infrastructure. }\end{array}$ & $\begin{array}{l}\text { Main local authorities, public } \\
\text { transport authorities, Dutch } \\
\text { Railways (NS) dissatisfied for } \\
\text { various reasons. }\end{array}$ \\
\hline 3 & $\begin{array}{l}\text { Institutional entrepreneurs } \\
\text { search for new ideas }\end{array}$ & $\begin{array}{l}\text { Gothenburg Region as the } \\
\text { organisation with responsibility } \\
\text { for regional planning sought } \\
\text { new ways to integrate spatial } \\
\text { and transport planning. }\end{array}$ & $\begin{array}{l}\text { Bus operator, political } \\
\text { representative and the CEO of } \\
\text { the VVB looked for ways to } \\
\text { accommodate Aachen's wishes. }\end{array}$ & $\begin{array}{l}\text { Initially more open, forward- } \\
\text { thinking authorities recognise } \\
\text { partnership working as way to } \\
\text { improve public transport. }\end{array}$ & $\begin{array}{llr}\text { Leading } & \text { authorities } & \text { and their } \\
\text { public transport } & \text { operators } \\
\text { searched for } & \text { possible } \\
\text { technologies. } & \end{array}$ \\
\hline 4 & Benchmark against new ideas & $\begin{array}{l}\text { Explicit benchmarking of the } \\
\text { effectiveness of formal vs } \\
\text { informal institutions was not } \\
\text { identified in interviews. }\end{array}$ & $\begin{array}{l}\text { Explicit benchmarking of the } \\
\text { effectiveness of formal vs } \\
\text { informal institutions was not } \\
\text { identified in interviews. }\end{array}$ & $\begin{array}{l}\text { Explicit benchmarking of the } \\
\text { effectiveness of formal vs } \\
\text { informal institutions was not } \\
\text { identified in interviews. }\end{array}$ & $\begin{array}{l}\text { Explicit benchmarking of the } \\
\text { effectiveness of formal vs } \\
\text { informal institutions was not } \\
\text { identified in interviews. }\end{array}$ \\
\hline 5 & $\begin{array}{l}\text { Institutional entrepreneurs use } \\
\text { their influence to spread the } \\
\text { new ideas }\end{array}$ & $\begin{array}{l}\text { Consensus building meetings } \\
\text { with municipalities convened by } \\
\text { Gothenburg Region. }\end{array}$ & $\begin{array}{l}\text { Many meetings both in the VVB } \\
\text { itself, in its operators' board, } \\
\text { and with the individual sub- } \\
\text { boards of each of the constituent } \\
\text { countries. }\end{array}$ & $\begin{array}{l}\text { Not identified directly in } \\
\text { interviews, beyond regular } \\
\text { interaction between parties. }\end{array}$ & $\begin{array}{l}\text { Promoters (as above) lobbied } \\
\text { other municipalities and } \\
\text { national government to secure } \\
\text { support and funding; and to } \\
\text { convince more local authorities } \\
\text { to integrate their land use with } \\
\text { the new scheme. }\end{array}$ \\
\hline 6 & $\begin{array}{l}\text { Window of opportunity to get } \\
\text { ideas adopted }\end{array}$ & $\begin{array}{l}\text { Both the K2020 process, and the } \\
\text { timescale for the fourth regional } \\
\text { plan. }\end{array}$ & $\begin{array}{l}\text { Annual fares review and } \\
\text { negotiation. }\end{array}$ & $\begin{array}{l}\text { When municipality has money } \\
\text { and political will, when local } \\
\text { bus services already quite } \\
\text { profitable and when right } \\
\text { personalities are in place in both } \\
\text { organisations. }\end{array}$ & $\begin{array}{l}\text { Yes, period between assembling } \\
\text { money and elections, for project } \\
\text { start. }\end{array}$ \\
\hline 7 & Potential for reactive moves & $\begin{array}{l}\text { Yes; any municipality could } \\
\text { drop out at any time. }\end{array}$ & $\begin{array}{l}\text { Yes, possible for any of the } \\
\text { political members of the VVB } \\
\text { to veto the proposal. }\end{array}$ & $\begin{array}{l}\text { Yes. Other operators not } \\
\text { included in partnership may } \\
\text { complain or take predatory } \\
\text { action. }\end{array}$ & $\begin{array}{l}\text { Yes, particularly if NS or } \\
\text { national government had } \\
\text { withdrawn support. }\end{array}$ \\
\hline 8 & New equilibrium is reached & $\begin{array}{l}\text { A more consensus-based } \\
\text { regional plan supporting the } \\
\text { wider objectives of K2020. }\end{array}$ & $\begin{array}{l}\text { Yes, but ultimately only because } \\
\text { the city that wanted the new fare } \\
\text { paid for it. }\end{array}$ & $\begin{array}{l}\text { Quality partnership in place } \\
\text { with more passengers and better } \\
\text { buses. }\end{array}$ & Scheme now in place. \\
\hline
\end{tabular}


The framework was designed to capture the process of institutional change, which is easier to identify in the case of formal institutions. In the case of informal institutions, the process is ongoing and more fluid, but in our cases the institutional setting resulting from the new scheme being introduced (incorporating the informal element) may be considered a new equilibrium. That is why the role of the informal must be considered in analysis of institutions because it is not always the formal institutions (instantiated mostly by formal transport organisations) that change but rather informal processes arise that change the overall institutional equilibrium, allowing the formal institutions to function more effectively.

What the analysis reveals is that the dissatisfaction with the old equilibrium does indeed produce the desire for change among institutional entrepreneurs, and the cases highlight that this change is not a clear evolutionary process of an individual making a discrete change but rather tends to be driven by many actors in a multi-faceted organic process. Moreover, the distinct nature of informal collaboration is that in the cases studied the goal was not to replace or even remodel the existing formal institutions. Rather, informal institutions were developed that supplemented the deficiencies of existing formal roles. It is also for this reason that the interviews did not reveal any explicit benchmarking of the new informal institutions against their formal counterparts, since the informal institutions were an addition to the institutional landscape and could not function without the formal institutions alongside them. This unique aspect of informal institutions reveals a potential weakness, in that their unplanned nature means that they just as likely to produce innovative solutions impossible within formal structures as to result in unworkable models that would have been identified had there been a more formal design and benchmarking process. Perhaps because of this view of the formal and informal as complementary, reactive moves were also few, as to some degree the old equilibrium was not actually challenged. On the other hand, this could also be interpreted as informal institutions being used to circumvent or get around formal procedures, hence the motivation not to appear to be challenging the formal institution, which could draw negative attention and perhaps a challenge to the emerging informal institution. What the analysis also reveals is that, while critical interfaces may involve conflict, when negotiated via informal institutions they appear less likely to do so.

Without the informal institutions that have been reviewed here, formal institutions for the management and improvement of public transport are likely to face even greater difficulties in delivering; good examples are the Verkehrsverbund in Germany, or large projects such as 
Randstadrail. In some cases, such as quality partnerships in England, very little would be delivered were it not for the informal institution, since no formal institution exists whose role it is to deliver what the informal institution is working towards. In terms of strengths, informal institutions clearly have flexibility, can be set up with relative speed (although may take many years to take on critical mass and become effective), and can deal with a range of issues. A weakness identified is that they at times risk being too exclusive, whereas a formal institution will normally have a mandated representation from certain groups.

A further distinction to make is that some of the informal processes nonetheless may develop a semi-formal mechanism, therefore they may not be as arbitrary as might be supposed. Nor are they placed in opposition to formal structures. For example, the memoranda of understanding used for voluntary bus partnerships in England or the Polder model in the Netherlands. The latter, as an informal institution, functions because the "rules of the game" are well known to those in the formal organisations, and so officials can easily fit in and play their role. At the regional and local level, there is stability of roles and people in organisations (in contrast to the national level), and personal contacts do play an important role. Municipalities, for example, know this, so the "smarter" ones use these personal contacts to influence decisions. Thus formal institutions allow informal institutions to exist and even provide them with a degree of freedom, perhaps evincing a recognition that they can achieve what formal organisations cannot.

\section{Conclusion}

In spite of the different categorisations or organisational collaboration models, it is still possible to identify a number of commonalities across the cases. Some are expected, and indeed are reasons for instituting governance in more formal institutions, such as the dependence on personal relationships, which on the other hand can put the institutions at risk since key people may leave. The key importance of trust and reciprocity identified in the literature on collaboration cited in section 2.1 relates both to this point and also to the identified need for the actors in these institutions to "speak the same language” whereby those who do not do so risk exclusion.

Beyond the informal activities themselves, conclusions may be drawn related to how the informal institution itself coheres, as opposed to the more visible presence of a formal institution which is normally an organisation or at least linked to one (or several). The 
informal institutions examined in this paper do not necessarily have a final concrete output but may instead be seen as part of a wider process, which can occasionally be a strength but is often perceived as a weakness. These institutions may produce reports or recommendations but these are then referred to a statutory decision making body for ratification. Perhaps of more interest is that, over time, the informal institutions may become so institutionalized that it is difficult to discern where the informal ends and the formal begins. A potential weakness from this reliance on informal institutions is that one important reason policy makers create formal governance institutions is due to the need for accountability, which informal institutions generally lack.

The literature reviewed in section 2.1 demonstrated the increasingly complex formal institutional structures that are found in the public transport sphere in Europe, often resulting in a lack of clear responsibility and agency to "get things done.” This paper has demonstrated that, in order to achieve a more ordered and functional system, it is often necessary to create an effective informal institutional structure. It thus supports the growing body of work identifying the importance of "steering cultures" to bind the various stakeholders together (Hansson, 2013; Hrelja, 2015).

The question does remain as to whether informal institutional forms are more effective than formal in improving public transport. The foregoing discussion has highlighted that certain projects would not have gone ahead or would have been further heavily delayed without these institutions; however, there is strong evidence that the two modes of governance are highly complementary. It is a recognised limitation of the research that the counter-factual has not been considered: we have not looked at case studies where the formal institutions are strong, vertically integrated, well-funded and with clear powers and responsibilities and can therefore work without reliance on informal institutions to deliver improvements to public transport. However, this does not make the research less relevant, since we have demonstrated that in several parts of Europe formal institutions are not of this nature and therefore the informal institutions are necessary to "fill the gap". It is also the case that the paper has not considered policy failure in informal institutions, but this point is addressed in our methodology section; research based only on relatively successful case studies is valid to understand how informal institutions can help deliver improvements to public transport, as long as it is borne in mind that these institutions may not deliver in every situation. Thus further research is needed on 
failed informal institutions, recognising the methodological difficulty in identifying them after the fact and then gathering relevant data.

It can be difficult within formal institutions to be able to take in and respond to new demands not defined within the formal, which produces a need for informal mechanisms. It allows organisations or industries made up of organisations to take advantage of new opportunities, such as joint applications for funding sources. Informal institutions thus become the lubricant between the formal legal definition, the powers and policies of an organisation and what it wants to do in practice. Far from existing institutions viewing informal institutions as a challenge, allowing the latter to flourish enables formal institutions to exert influence over tasks that are outwith their formally defined area of influence. Moreover, findings reveal evidence of informal institutions acting not as a replacement for formal institutions, but as a mechanism to hold the formal system together. There is some evidence that, despite an official hierarchy of institutions in many policy arenas such as transport, we live now in a less hierarchical, more fragmented society, which produces a need for "softer" institutions to bind things together.

\section{Acknowledgements}

The work is part of a research project (Collaborative Models for Better Public Transport) funded by the Swedish research funding organisation Vinnova from 2013 to 2016 (Dnr 201303020) and carried out by researchers who are part of the Swedish National Public Transport Research Centre, K2 (www.k2centrum.se). The authors would like to thank all the interviewees who contributed their time and also our collaboration partners from the different regions. 


\section{References}

Aoki, M. (2007). Endogenizing institutions and institutional changes. Journal of Institutional Economics. 3 (1): 1-31.

Amin, A., Thrift, N. J. (1995). Globalization, institutional "thickness" and the local economy. In P. Healey, S. Cameron, S. Davoudi, S. Graham, A. Madinpour (eds). Managing Cities, The New Urban Context. Chichester: Wiley.

Berman, W., Smith, M., Bauer, J. (2005). Regional concept for transportation operations. A tool for strengthening and guiding collaboration and coordination. Transportation Research Record. 1925: 245-253.

Coase, R. H. (1983). The new institutional economics. Journal of Institutional and Theoretical Economics. 140 (1): 229-231.

González, S., Healey, P. (2005). A sociological institutionalist approach to the study of innovation in governance capacity. Urban Studies. 42 (11): 2055-2069.

Go Ahead Group Brighton Buses (2015) http://www.buses.co.uk/information/aboutus.aspx accessed 1st July 2015

Gray, D., Laing, R., and Docherty, I. (2017) Delivering lower carbon urban transport choices: European ambition meets the reality of institutional (mis)alignment. Environment and Planning A 2017. Vol. 49(1) 226-242.

Groenewegen, J., De Long, M. (2008). Assessing the potential of new institutional economics to explain institutional change: the case of road management liberalization in the Nordic countries. Journal of Institutional Economics. 4 (1): 51-71.

Hall, P. A., Taylor, R. C. R. (1996). Political science and the three new institutionalisms. Political Studies. 44 (5): 936-957.

Hansson, L., 2013. Hybrid steering cultures in the governance of public transport: a successful way to meet demands? Res. Transport. Econ. 39 (1), 175-184.

Hrelja, R, Pettersson, F., Westerdahl, S. 2016. The qualities needed for a successful collaboration: A contribution to the conceptual understanding of collaboration for efficient public transport. Sustainability, 8(6), 542.

Hrelja, R. 2015. Integrating transport and land-use planning? How steering cultures in local authorities affect implementation of integrated public transport and land use planning. Transportation Research Part A: Policy and Practice. Vol. 74, pp 1-13.

Hrelja, R., Hansson, L., Richardson, T., Svensson, T., Lissandrello, E., Næss, P., Tennøy, A., Longva, F. 2013. Innovations for sustainable public transport: experiences and challenges in the Scandinavian countries. VTI-report 799, Linköping. 
Hrelja, R., Rye, T., Mullen, C. (2017). Partnership working between operators and public transport authorities. Qualities and working practices for functioning collaboration. Paper accepted at 15th Thredbo Conference on Passenger Transport Regulation, Stockholm, August 2017.

Jessop, B. (2001). Institutional (re)turns and the strategic-relational approach. Environment \& Planning A. 33 (7): 1213-1235.

Kingdon, J. W. (1984). Agendas, Alternatives and Public Policies. Boston: Little, Brown and Company.

March, J. G., Olsen, J. P. (1984). The new institutionalism: organizational factors in political life. American Political Science Review. 78 (3): 734-749.

Marsden, G., May, A. D. (2006). Do institutional arrangements make a different to transport policy and implementation? Lessons for Britain. Environment and Planning C. 24: 771789.

Marsden, G., Mullen, C., Bache, I., Bartle, I., Flinders, M. (2014). Carbon reduction and travel behaviour: discourses, disputes and contradictions in governance. Transport Policy. 35: 71-78.

Marsden, G and Groer, S (2016). Do institutional structures matter? A comparative analysis of urban carbon management policies in the UK and Germany. Journal of Transport Geography. 51 (2016) 170-179.

Martin, R., 2000. Institutional approaches in economic geography. In: Sheppard, E., Barnes, T. J., (Eds.), A Companion to Economic Geography. Malden: Blackwell.

Martin, R. (2010). Roepke lecture in economic geography. Rethinking regional path dependence: beyond lock-in to evolution. Economic Geography. 86 (1): 1-27.

Monios, J. (2017). Policy transfer or policy churn? Institutional isomorphism and neoliberal convergence in the transport sector. Environment and Planning A. 49 (2): 351-371.

Monios, J., Lambert, B. (2013). The heartland intermodal corridor: public-private partnerships and the transformation of institutional settings. Journal of Transport Geography. 27 (1): $36-45$.

Ng, A. K. Y., Pallis, A. A. (2010). Port governance reforms in diversified institutional frameworks: generic solutions, implementation asymmetries. Environment \& Planning A. 42 (9): 2147-2167.

North, D. C. (1990). Institutions, Institutional Change and Economic Performance. Cambridge: Cambridge University Press. 
North, D.C (1991) Institutions. The Journal of Economic Perspectives, Vol. 5, No. 1, (Winter, 1991), pp. 97-112 Published by: American Economic Association Stable

Pangbourne, K. (2007). Issues of Geography in Scottish Transport Governance. Conference Proceedings of the 2007 STAR Conference (Scottish Transport Applications \& Research).

Pemberton, S., 2000. Institutional governance, scale and transport policy - lessons from Tyne and Wear. Journal of Transport Geography 8(4), 295-308.

Powell, W.W., 1990. Neither market nor hierarchy. Network forms of organization. Research in organizational behaviour 12 (2), 295-336.

Priemus, H. (1999) Coordination in Planning Public Transport: Evidence from the Netherlands, Planning Practice \& Research, 14:1, 97-106.

Rivasplata, Charles, Iseki, Hiroyuki, 2012, Transit Coordination in the U.S. A Survey of Current Practice. Journal of Public Transportation, Vol. 15, No. 1, 2012

Rye, T and Wretstrand, A. (2014) Converging structures? Recent regulatory change in busbased local public transport in Sweden and England. Research in Transport Economics Vol 48 pp 24-32.

Schön, D. A., Rein, M. (1994). Frame Reflection: Toward the Resolution of Intractable Policy Controversies. New York: Basic Books.

Scott, W. R. (2008a). Approaching adulthood: the maturing of institutional theory. Theory \& Society. 37 (5): 427-442.

Scott, W. R. (2008b). Institutions \& Organizations. $3^{\text {rd }}$ ed. Los Angeles: Sage.

Selznick, P. (1996). Institutionalism “old” and “new”. Administrative Science Quarterly. 41 (2): $270-277$.

Shaw, J., MacKinnon, D., Docherty, I. (2009). Divergence or convergence? Devolution and transport policy in the United Kingdom. Environment \& Planning C. 27 (3): 546-567.

Sørensen, C. H., Gudmundsson, H. (2010). The impact of governance modes on sustainable transport - the case of bus transport in Greater Manchester, UK. World Review of Intermodal Transportation Research. 3 (1/2): 8-25.

Sørensen, C.H., Longva, F 2011, Increased coordination in public transport-which mechanisms are available? Transport Policy, Volume 18, Issue 1, January 2011, Pages 117-125.

Van de Velde, D., Wallis, I. (2013). 'Regulated deregulation’ of local bus services-An appraisal of international developments. Research in Transportation Economics. 39 (1): 21-33. 
Welsch, J., Haustein S., and Kemming, H. 2008. MAX Project WP D Common Analysis Framework Germany. ILS Dortmund, Germany. See www.epomm.eu

Williamson, O. E. (1975). Markets and Hierarchies: Analysis and Antitrust Implications. New York: The Free Press.

Williamson, O. E. (1985). The Economic Institutions of Capitalism. New York: The Free Press.

Woldendorp, J. and Keman, H. 2007 The Polder Model reviewed: Dutch corporatism 19652000. Economic and Industrial Democracy 28(3): 317-347.

Yin, R. (2009). Case Study Research. Thousand Oaks, CA: Sage. 